DOI: $\underline{\text { https://doi.org/10.31933/dijdbm.v2i2 }}$

Received: 6 January 2021, Revised: 15 February 2021, Publish: 1 March 2021

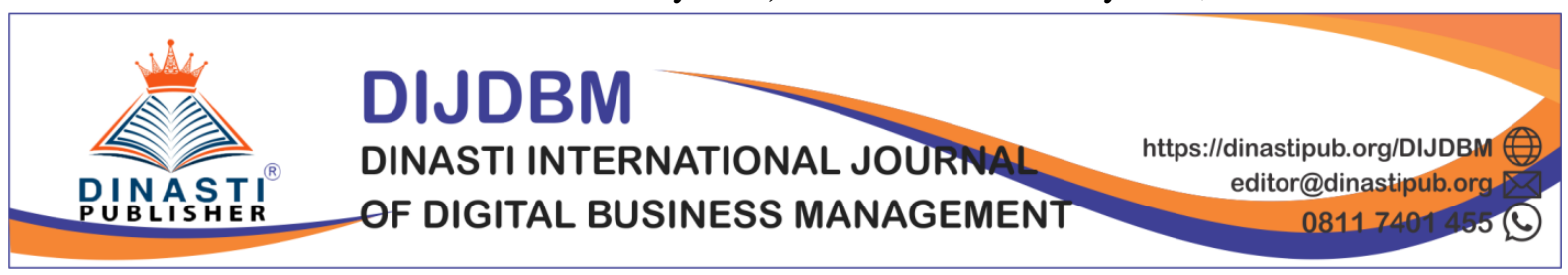

\title{
THE EFFECT OF LEADERSHIP, JOB SATISFACTION, ORGANIZATIONAL CITIZENSHIP BEHAVIOUR AND COMPETENCE ON EMPLOYEE PERFORMANCE (CASE STUDY AT XYZ MINISTRY IN INDONESIA)
}

\author{
Rini Tri Rejeki ${ }^{1}$, Aslam Mei Nur Widigdo ${ }^{2}$ \\ ${ }^{1)}$ Universitas Mercu Buana, Jakarta, Indonesia, rinitrirejeki78@gmail.com \\ ${ }^{2)}$ Universitas Mercu Buana, Jakarta, Indonesia, aslam.mei@mercubuana.ac.id
}

\section{Corresponding Author: Rini Tri Rejeki}

\begin{abstract}
This research has purpose to discover the affect of leadership, job satisfaction, organizational citizenship behavior, and competence on employee performance in XYZ Ministry. The research method used quantitative approach with the type of research is included in causal research. The research population was 1,587 permanent employees at Work Units and Technical Implementation Units of XYZ Ministry in Jabodetabek. The sampling technique was proportional stratified random sampling with the number of samples was 94 employees. These research data were obtained by distributing questionnaires. The quantitative data analysis method uses multiple linear regression methods. The results showed if 1) Leadership partially has the strongest and significant impact on employee performance. 2) Job satisfaction partially has a significant impact on employee performance. 3) Organizational citizenship behavior partially has a significant impact on employee performance. 4) Employee competence partially has a significant impact on employee performance. 5) Leadership, job satisfaction, organizational citizenship behavior and employee competence simultaneously have a significant impact on employee performance.
\end{abstract}

Keywords: Leadership, job satisfaction, employee competence, organizational citizenship behavior, employee performance.

\section{INTRODUCTION}

Human resources are one of the production factors that play an important role in an organization in order to achieve the goals. Human resources have shown as the main keys that should be adjusted with all their needs. Based on Ministerial Regulation Number 122 of 2018, XYZ Ministry have the task of carrying out the implementation of human resource development. The XYZ Ministry has duty to conducted an education or training to its employees who spread throughout Indonesia.

During the period of 2016 to 2018, the XYZ Ministry had experienced several decreases in performance accomplishment which could be seen from budget absorption or budget realization. Performance is the result of work in quality and quantity achieved by an employee in carrying out their duties in accordance with the responsibilities assigned to him. In increasing performance, the XYZ Ministry (2014-2019) has targets that need to be 
realized, including increasing the maximum of the management of performance accountability, budgets and State Property. The performance of public institutions could be seen from several indicators, such as budget absorption. According to the data on the realization of the XYZ Ministry budget per year, it shows that the target of budget absorption has not been achieved and tends to decline.

Table 1. XYZ Ministry' Budget Realization Report during 2016 until 2019

\begin{tabular}{cccc}
\hline No & Year & Target $(\boldsymbol{\%})$ & Realization $(\boldsymbol{\%})$ \\
\hline 1 & 2016 & 95.12 & 78.71 \\
2 & 2017 & 92.84 & 89.73 \\
3 & 2018 & 91.00 & 85.16 \\
\hline
\end{tabular}

The unachieved target of performance at XYZ Ministry caused by various obstacles. Based on pre-survey research conducted by spreading questionnaires to $30 \mathrm{ASN}$ employees at the XYZ Ministry HR Development Center, the main factors that are causing the employee performance failed to achieved are leadership (17\%), competence (20\%), job decision (13\%) and organization citizenship behavior (17\%).

Table 2. Factor that Affect Employee Performance

\begin{tabular}{clcc}
\hline No. & \multicolumn{1}{c}{ Factor that Affect Employee Performance } & Frequency & Percentage \\
\hline $\mathbf{1}$ & Leadership & $\mathbf{5}$ & $\mathbf{1 7 \%}$ \\
2 & Work Environment & 2 & $7 \%$ \\
3 & Team Work and Colleagues & 2 & $7 \%$ \\
$\mathbf{4}$ & Competence & $\mathbf{6}$ & $\mathbf{2 0 \%}$ \\
5 & Training \& Career Development & 2 & $7 \%$ \\
6 & Organizational Policy & 2 & $7 \%$ \\
7 & Workplace Wellbeing & 2 & $7 \%$ \\
$\mathbf{8}$ & Job Satisfaction & $\mathbf{4}$ & $\mathbf{1 3 \%}$ \\
$\mathbf{9}$ & Organizational Citizenship Behavior & $\mathbf{5}$ & $\mathbf{1 7 \%}$ \\
\hline
\end{tabular}

Based on the background above and the pre-survey findings, the problem statement is whether the leadership, job satisfaction, organization citizenship behavior and competence affects the employees performance at XYZ Ministry either way partially or simultaneously?

The aims of this research was to find out and analyze the influence of leadership, job satisfaction, organizational citizenship behavior, and competence on the employee performance at XYZ Ministry partially or simultaneously.

\section{LITERATURE REVIEW}

According to Schermerhorn (1989) in Almutairi \& Abdulaziz (2016), work performance is the result of quality and quantity after employees accomplished the tasks. Furthermore, Sedarmayanti (2011: 54) in Alfiyah \& Riyanto (2019) revealed if the increased of employee performance could be evaluated from the increased of achievement on organizational succeed that could achieve predetermined organizational goals. $\mathrm{Hu}$ et al. (2014:34) Which stated if the employee performance could be measured by three dimensions, such as task performance, contextual performance and innovative performance. 
Robbins (2015) in Irnawati \& Prasetyo (2020) says if the leadership is the ability to influence groups on reaching the goals. Mulki, et al. (2014: 5) stated if the leadership could be divided in two dimensions, namely the initiating structure (instrumental) style and the consideration (supportive or participative) style.

Job satisfaction is a positive feeling about someone's job and work arrangements (UhlBien et al., 2016:15). Job satisfaction comes from the difference between what is wanted or what benefits obtained from the job and what is expected from it (Locke, 1976) in (Drydakis, 2017:3) Furthermore, Tsai (2015:313) stated if the job satisfaction could be measured by five dimensions, namely salary, job, position advancement, supervisors, and colleagues.

Organizational Citizenship Behavior (OCB) is considered sufficient in terms of finance and human resources, as well as helping the organization efficiency in operations (Qiu et al., 2019:78). Chan \& Lai (2017:215) revealed that Organizational Citizenship Behavior (OCB) could be measured by five dimensions, such as responsibility in the organization (civic virtue), working without complaining (sportsmanship), behavior maintaining good relations (courtesy), behavior which shows more than a minimum requirement (conscientiousness) and behavior to help others (altruism).

McClelland (1973) in Chouhan \& Srivastava (2014:15) defined competence as a personal trait or a set of habits that lead to more effective or superior job performance, in other words, abilities that add a clear economic value to someone's efforts at work. Furthermore, Otoo (2019:260) said that the measurement of employee competence is measured by the dimensions of self-competence, cooperation competence, change competence, communication competence and ethical competence.

Leadership and competence partially have a significant impact on employee performance (Widodo, 2017). Employee performance could be enhanced through programs which could elevate the competence (Mardiyah \& Purba, 2019). Chiang \&Hsieh (2012) found that organizational citizenship behavior partially have a direct and significant impact on employee performance. Besides its capability to directly influence employee performance, job satisfaction could also act as a mediating variable (Lestari \& Ghaby, 2018).

Based on prior research and those review of theories related to leadership, job satisfaction, organizational citizenship behavior, and employee performance, the theoretical framework for this research model could be seen as it shown in Figure 1. 


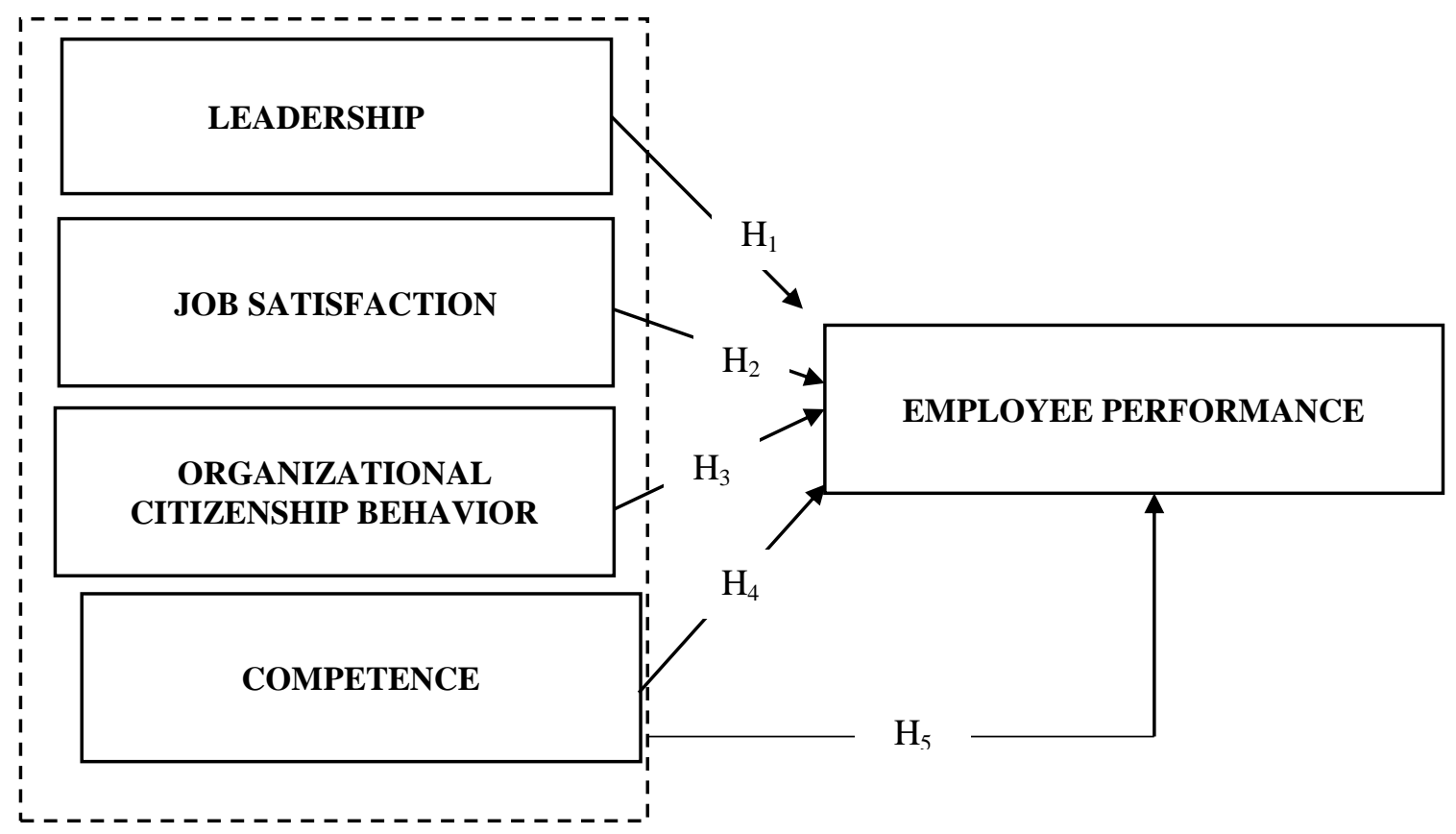

Figure 1. Theoretical Framework

The research hypothesis that could be presented as follows:

1) The Leadership affects employee performance.

2) Job satisfaction affects employee performance.

3) Organizational citizenship behavior affects employee performance.

4) Competence affects employee performance.

5) Leadership, job satisfaction, organizational citizenship behavior, and competence simultaneously (simultaneously) affect employee performance.

\section{RESEARCH METHODS}

This research used a quantitative approach with type of causal research. The research population was permanent employees at the Work Unit and Technical Implementation Unit at XYZ Ministry in Jabodetabek, with number of 1,587 people. Sampling technique of research was proportional stratified random sampling with the sample size was 94 employees. Types of data used in this research are primary data and secondary data, while the research instrument is a questionnaire with a Likert scale of 1-5 which is distributed to research respondents to gather the research data. After all the data research gathered then analyzed through multiple linear regression analysis by the research instrument and hypothesis test.

\section{RESULT AND DISCUSSION Research Result}

The results showed that the t-count of the leadership variable was 4.358 and Sig. 0.000 $<0.05$; $\mathrm{t}$-count of job satisfaction variable was 3.082 and Sig. $0.003<0.05$; $\mathrm{t}$-count of OCB variable was 2.768 with Sig. $0.007<0.05$; and t-count of employee competence variables was 2.992 with Sig. $0.004<0.05$, then it could be concluded that both leadership variables, job satisfaction variables, OCB variables and competence variables partially has a positive and 
significant impact on employee performance at XYZ Ministry, meaning that $\mathrm{H} 1, \mathrm{H} 2, \mathrm{H} 3$, and $\mathrm{H} 4$ were accepted. The regression equation which resulting from these data processing as follows: $\mathrm{Y}=3.555+0.293 \mathrm{X}_{1}+0.149 \mathrm{X}_{2}+0.142 \mathrm{X}_{3}+0.137 \mathrm{X}_{4}$

The $\mathrm{F}$ test and $\mathrm{R}^{2}$ test results shows if the F-count was 95,933 with Sig. 0,000< $\mathrm{Sig}$. 0.05 , thus it could be concluded that H5 which stated that the leadership, job satisfaction, $\mathrm{OCB}$, and competence simultaneously affects the employees performance at XYZ Ministry was accepted. The simultaneous affect was around $80.3 \%$, while the remaining $19.7 \%$ was determined by other factors outside this research, such as organizational culture, organizational commitment, and work motivation

Table 3. Multiple Linear Regression Analysis Results

\begin{tabular}{|c|c|c|c|c|c|c|}
\hline \multirow{2}{*}{\multicolumn{2}{|c|}{ Model }} & \multicolumn{2}{|c|}{ Unstandardized Coefficients } & $\begin{array}{c}\text { Standardized } \\
\text { Coefficients }\end{array}$ & \multirow[b]{2}{*}{$\mathrm{t}$} & \multirow[b]{2}{*}{ Sig. } \\
\hline & & $\mathrm{B}$ & Std. Error & Beta & & \\
\hline \multirow[t]{8}{*}{1} & (Constant) & 3.555 & 3.742 & & .950 & .345 \\
\hline & Leadership & .293 & .067 & .294 & 4.358 & .000 \\
\hline & Job Satisfaction & .149 & .048 & .276 & 3.082 & .003 \\
\hline & $\mathrm{OCB}$ & .142 & .051 & .214 & 2.768 & .007 \\
\hline & Competence & .137 & .046 & .236 & 2.992 & .004 \\
\hline & ANOVA $\left(\mathbf{F}_{\text {hitung }}\right)$ & & & & 95.933 & $.000^{b}$ \\
\hline & $\mathrm{R}$ (multiple regression) & & & & .901 & \\
\hline & Adjusted R Square & & & & .803 & \\
\hline
\end{tabular}

\section{Inter-Dimensional Correlation}

Based on the inter-dimensional correlation test result through the pearson correlations formula sample of 94 respondents, the results could be form as follows: the initiating structure dimensions have a strong and significant correlation with the contextual performance dimension. The consideration dimension has a strong and significant correlation with the innovative performance dimension.

The correlation test results between dimensions on job satisfaction and employee performance shows that the dimensions of salary have a strong and significant correlation with contextual performance. The job dimension has a strong and significant correlation with the task performance dimension. The dimensions of position advancement are moderately and significantly correlated with the contextual performance dimension and so with the innovative performance are. The supervisor dimension has a moderate and significant correlation with the contextual performance dimension. The co-worker dimension has a moderate and significant correlation with the contextual performance dimension.

The correlation test results between dimensions on the variable organizational citizenship behavior and employee performance shows if the civic virtue dimension has a strong and significant correlation with the task performance dimension. The sportsmanship dimension has a strong and significant correlation with task performance dimension. The courtesy dimension has a moderate and significant correlation with task performance. The conscientiousness dimension has a moderate and significant correlation with the task performance dimension. The altruism dimension has a strong and significant correlation with contextual performance. 
The correlation test results between dimensions on employee competency variable and employee performance shows that the dimensions of self-competence have a moderate and significant correlation with innovative performance. The cooperation competence dimension has a moderate and significant correlation with innovative performance. The Transform of competence dimension has a moderate and significant correlation with innovative performance. The communication competence dimension has a significant correlation with task performance. The ethical competency dimension has a strong and significant correlation with contextual performance. The knowledge dimension has a strong and significant correlation with contextual performance. The skill dimension has a moderate and significant correlation with contextual performance. The attitude dimension has a moderate and significant correlation with contextual performance.

Table 4. Inter-Dimensional Correlation Results

\begin{tabular}{|c|c|c|c|c|}
\hline Dimension & & $\begin{array}{c}\text { Y1.1 } \\
\text { Task } \\
\text { Performance }\end{array}$ & $\begin{array}{c}\text { Y1.2 } \\
\text { Contextual } \\
\text { Performance }\end{array}$ & $\begin{array}{c}\text { Y1.3 } \\
\text { Inovative } \\
\text { Performance }\end{array}$ \\
\hline Initiating Structure & $\mathrm{X} 1.1$ & $.586^{* *}$ & $.748^{* * \pi}$ & $.644^{* * *}$ \\
\hline Consideration & $\mathrm{X} 1.2$ & $.432^{* *}$ & $.522^{* *}$ & $.789^{* *}$ \\
\hline Sallary & $\mathrm{X} 2.1$ & $.673^{* *}$ & $.717^{* *}$ & $.578^{* *}$ \\
\hline Profession & $\mathrm{X} 2.2$ & $.641^{* *}$ & $.616^{* * *}$ & $.571^{* * *}$ \\
\hline Career Advancement & $\mathrm{X} 2.3$ & $.486^{* *}$ & $.510^{* *}$ & $.510^{* *}$ \\
\hline Supervisor & X2.4 & $.430^{* *}$ & $.467^{* *}$ & $.435^{* *}$ \\
\hline Co-workers & $\mathrm{X} 2.5$ & $.474^{* *}$ & $.534^{* *}$ & $.484^{* *}$ \\
\hline Civic Virtue & $\mathrm{X} 3.1$ & $.724^{* *}$ & $.686^{* *}$ & $.503^{* *}$ \\
\hline Sportsmanship & X3.2 & $.751^{* *}$ & $.643^{* *}$ & $.434^{* *}$ \\
\hline Courtesy & X3.3 & $.447^{* *}$ & $.434^{* * *}$ & $.403^{* *}$ \\
\hline Conscientiousness & X3.4 & $.473^{* *}$ & $.287^{* *}$ & $.281^{* *}$ \\
\hline Altruism & X3.5 & $.638^{* * *}$ & $.755^{* * *}$ & $.411^{* *}$ \\
\hline Self-competence & $\mathrm{X} 4.1$ & $.489^{* *}$ & $.442^{* *}$ & $.494^{* *}$ \\
\hline Cooperation Competence & $\mathrm{X} 4.2$ & $.531^{* *}$ & $.518^{* *}$ & $.574^{* *}$ \\
\hline Transform Competence & $\mathrm{X} 4.3$ & $.340^{* *}$ & $.343^{* *}$ & $.332^{* *}$ \\
\hline Communication Competence & $\mathrm{X} 4.4$ & $.485^{* *}$ & $.449^{* *}$ & $.465^{* *}$ \\
\hline Ethical Competence & $\mathrm{X} 4.5$ & $.571^{* *}$ & $.646^{* *}$ & $.456^{* *}$ \\
\hline Knowledge & $\mathrm{X} 4.6$ & $.552^{* *}$ & $.707^{* *}$ & $.400^{* *}$ \\
\hline Skills & $\mathrm{X} 4.7$ & $.458^{* *}$ & $.526^{* *}$ & $.339^{* *}$ \\
\hline Attitude & $\mathrm{X} 4.8$ & $.305^{* *}$ & $.523^{* *}$ & $.337^{* *}$ \\
\hline
\end{tabular}

\section{Discussion}

The research result shows that leadership partially has the strongest and significant impact on employee performance at XYZ Ministry. This will compatible with the theoretical use of leadership behavior, in which followers (employees) feel more satisfied with their work and would be more motivated and have more respect towards their leaders who practice caring leadership. Meanwhile, for the leadership style, the initial structure (Initiating structure) is stronger relation with higher levels of group and organizational productivity and lots of positive performance evaluation (Robbins \& Judge, 2017: 424).

Based on these calculation results of the inter-dimensional correlation, it could be seen clearly if the lowest inter-dimensional correlation results occurs in the consideration dimension with the task performance dimension. This is because superiors pay less attention to employee welfare. Employee welfare issues such as salaries and incentives are determined 
by the government according to class /rank and work load. Then, the boss did not treat each employee fairly because there are indeed employees who have different working hours, and even overtime, then sometimes the employees who work late until late at night will come to work a little later because of work fatigue

Meanwhile, the strongest inter-dimensional correlation occurs in the consideration (supportive or participative) dimensions with innovative performance dimension. The increase in employee innovative performance is because superiors are willing to listen to recommendations from the employees regarding job assignments. Superiors feel the need to get all constructive input to get comprehensive information in completing work tasks with maximum results. Then, the boss also begs to his/her subordinates so when carrying out their job duties they should be filled with pleasure.

As for what should be improved in the Work Unit and Technical Implementing Unit at XYZ Ministry such as Bosses need to encourage (stimulate) their subordinate staff to be more innovative in providing thought-provoking suggestions when finding new problems in work so that work assignment problems wont be a matter for them for a long time in order to complete their work.

Job satisfaction partially has a significant impact on employee performance at XYZ Ministry. It is appropriate if the use of equity theory refers to balancing or calibrating an employee's inputs and outputs. Based on these inter-dimensional correlation test results, it is clear that the lowest inter-dimensional correlation occurs in the supervisor dimension and the task performance dimension. The low performance on a job is caused by the boss not treating employees fairly. When there are so many work assignments (overload), superiors continue to delegate work tasks to their subordinate staff, who are already full of workload.

Meanwhile, the strongest inter-dimensional correlation occurs in the salary dimension with the contextual performance dimension. It is because of a satisfactory salary which, according to employee expectations, will increase the enthusiasm for work because employees get the desired income and enough to fulfill their daily needs.

As for things that should be improved at the Work Unit and Technical Implementing Unit at XYZ Ministry, such as superiors who are more polite and do not show a high temper attitude when the work tasks of their subordinate staff have not been completed. Likewise, their subordinate staff must be more dexterous at work and further increase the initiative to help colleagues who are busy at work, then whole tasks could be completed. Organizational citizenship behavior partially has a significant impact on employees' performance at XYZ Ministry. Those are in line with the theoretical use of social exchange, such as when employees experience satisfaction in workplace communication, their satisfaction is likely to be expressed by engaging in additional role behaviors (Chan \& Lai, 2017:215).

Furthermore, based on the inter-dimensional correlation test results, it is clear that the lowest inter-dimensional correlation test results occur in the conscientiousness dimension with the innovative performance dimension. The cause of employees having low innovative performance is because employees are not careful in completing their work tasks. Job assignments are completed hastily without being scrutinized after completing work, so it results are not optimal. Moreover, when the supervision which is carried out by the institution is low, of course employees use this chance to be less disciplined at work. Employees who 
lack discipline would return from work even though it is not convenient time to come home from work.

Meanwhile, the strongest interdimensional correlation occurs in the altruism dimension with the contextual performance dimension. The attitude and behavior of employees who are enthusiastic about working together and helping each other to their colleagues results in work tasks being completed quickly. Even though each employee has their respective job duties and responsibilities, when asked for help from their colleagues they would show a willingness to help.

As for things that should be improved at Work Unit and the Technical Implementation Unit at XYZ Ministry, namely, each employee staff should have a high understanding of helping each other's colleagues who are busy completing work tasks. Work cannot be completed perfectly without cooperation among workers. Therefore, it is very important that there is an initiative from colleagues to help other colleagues who have tons of work assignments.

Employee competence partially has a significant impact on employee performance at XYZ Ministry. These research findings are in accordance with the explanation of competency theory, which is the ability needed in the workplace, including personal potential capacity.

Based on these inter-dimensional correlation test results, it is clearly seen that the lowest inter-dimensional correlation results occur in the dimensions of Transform competence with the dimensions of innovative performance. The reason why it has low results was due to inappropriate restructuring changes, where the placement of employees who are not competent in their respective field which has results in less job tasks that are being completed. Furthermore, job training is not given equally and those training is not adjusted to their main job duties, so it won't make any different changes.

Meanwhile, the strongest inter-dimensional correlation occurs in the knowledge dimension with the contextual performance dimension. The increase in contextual performance was due to employees having good abilities in making work reports. The ability of employees in making work reports is because employees received training and gained experience. Furthermore, employees who received training are quick to complete work assignments. In fact, employees who already have this knowledge and experience become fast at teaching their colleagues in understanding the completion of work tasks.

As for things that should be improved at the Work Unit and Technical Implementing Unit in XYZ Ministry, such as employees who are apparently still not able to improve their knowledge could be given training/retraining until they understand and capable to adjust to work changes so they would be more productive.

Leadership, job satisfaction, organizational citizenship behavior, competence together have a significant impact on employee performance at XYZ Ministry. From the simultaneous test results or ANOVA, it is clear if the factors that affect the employees performance at XYZ Ministry include leadership, job satisfaction, OCB and competence. These factors are considered important in improving the employees performance at XYZ Ministry because the leaders provide the opportunity for subordinate staff to convey ideas then the leaders would consider about it. 
Then, if the idea is accepted in decision making, then it will increase the employees satisfaction at XYZ Ministry employees and it would have an impact on the achievement of tasks and employees performance of the employees themselves. The research findings indicate that intrinsically oriented employees are more likely to be satisfied the employees than extrinsically oriented because there is no evidence to support a positive relations between extrinsic reward-based assessments and long-term improvements in performance quality.

By creating job satisfaction, it will indirectly affect employee involvement in the organization. With this involvement, employees will initiate voluntary action outside of their job roles, make sacrifices, help others and offer advice. These things will certainly have an impact on the employees performance themselves.

The simultaneous test results also show that the competence aspect is considered as an important because it has a significant affects on employee performance. Workers cannot reach the standards without competence. But competence cannot guarantee the workers will perform adequately. Employees who lacked competence will find it difficult to complete work tasks properly. From these research findings, it is known that the employees have selfcompetence so the employees are brave enough to faced job task challenges which are felt to be new and employees would be able to completed a number of work things well.

\section{CONCLUSION, MANAGERIAL IMPLICATION, AND SUGGESTION Conclusion}

According to the hypothesis test results and the research discussions above, thus several conclusions that could written as follows:

1) The leadership partially has strong and significant affect on employees performance at XYZ Ministry.

2) Job satisfaction partially has a significant affect on employees performance at $X Y Z$ Ministry.

3) Organizational citizenship behavior partially has a significant affect on employees performance at XYZ Ministry.

4) Competence partially has a significant affect on employees performance at $X Y Z$ Ministry.

5) Leadership, job satisfaction, organizational citizenship behavior, competence simultaneously affect employee performance at XYZ Ministry.

\section{Managerial Implication}

Based on those findings, the managerial implications which could be conveyed and advised are such below:

1) In order to make the superiors more attentive towards the employees welfare by providing the incentives according to job duties and responsibilities to employees who are indeed outstanding so this could improve the employee performance;

2) The management of the organization should pick employees who show brilliant performance to get promoted to a higher position, then it will automatically increase the employee salaries; employees are advised to be aware of completing the job assignments 
given by their superiors, so the results of their work are in accordance with what is expected;

3) Employees are advised to regularly evaluate employee performance in order to determine the quality of employees at work;

4) Fellow colleagues need to show a harmonious attitude of cooperation and help each other so the performance earned by the organization could be better in the future.

\section{Suggestion}

Based on these research findings, the managerial suggestions that could be written such as the superiors are advised to be concerned about the welfare of their employees by providing incentives according to job duties and their responsibilities to the employee who excels the work so it would improve the employee performance; organizational management should recommend employees who have brilliant performance to get promoted to a higher position, then it will automatically increase their salaries; employees are considered to be more careful in terms of accomplished job assignments that are given by their superiors, so their work results will according to what is expected; employees are advised to periodically evaluate employee performance in order to find out the quality of employees at work; fellow colleagues need to show a harmonious attitude of cooperation and help each other, which will create better performance produced by the organization; Further research is advised to do further research regarding other variables which have impact towards employee performance in human resource development agencies such as organizational culture, organizational commitment and work motivation, then using the SEM method as well for their data analysis.

\section{REFERENCE}

Alfiyah, N., \& Riyanto, S. (2019). The Effect of Compensation, Work Environment and Training on Employees' Performance of Politeknik LP3I Jakarta. International Journal of Innovative Science and Research Technology, 4(5), 947-955.

Almutairi, D. O., \& Abdulaziz, K. (2016). The Mediating Effects of Organizational Commitment on the Relationship between Transformational Leadership Style and Job Performance. International Journal of Business and Management, 11 (1), 231-241.

Chan, S. H. J., \& Lai, H. Y. I. (2017). Understanding the link between communication satisfaction, perceived justice and organizational citizenship behavior. Journal of Business Research, 70, 214-223. 10.1016/j.jbusres.2016.08.017

Chiang, C.-F., \& Hsieh, T.-S. (2012). The impacts of perceived organizational support and psychological empowerment on job performance: The mediating effects of organizational citizenship behavior. International Journal of Hospitality Management, 31(1), 180-190. 10.1016/j.ijhm.2011.04.011

Chouhan, V.S., \& Srivastava, S. (2014). Understanding Competencies and Competency Modeling - A Literature Survey. IOSR Journal of Business and Management, 16(1), 14-22.

Drydakis, N. (2017). Trans employees, transitioning, and job satisfaction. Journal of Vocational Behavior, 98, 1-16. 10.1016/j.jvb.2016.09.003 
Hu, X., Kaplan, S., Wei, F., \& Vega, R. P. (2014). Employees' metaperceptions of supervisor ratings on job performance. The Psychologist-Manager Journal, 17, 30-48. 10.1037/mgr0000010

Irnawati, J.E., \& Prasetyo, J.H. (2020). The Influence Over the Transformational of Leadership Style, the Organizational Culture, and Employee Empowerment towards Achievement of Organizational Strategies in one the Central Government Organization. International Journal of Innovative Science and Research Technology, 5(3), 917-927.

Lestari, E. R., \& Ghaby, N. K. F. (2018). Pengaruh Organizational Citizenship Behavior (OCB) terhadap Kepuasan Kerja dan Kinerja Karyawan. Industria: Jurnal Teknologi dan Manajemen Agroindustri, 7(2), 116-123. 10.21776/ub.industria.2018.007.02.6

Mardiyah, A., \& Purba, C.B. (2019). The Effects of Competency, Training and Education, and Career Development on Employees' Performance at Hermina Hospital Kemayoran. International Journal of Innovative Science and Research Technology, 4(6), 313-323.

Mulki, J. P., Caemmerer, B., \& Heggde, G. S. (2014). Leadership style, salesperson's work effort and job performance: the influence of power distance. Journal of Personal Selling \& Sales Management, 35(1), 3-22. 10.1080/08853134.2014.958157

Otoo, F. N. K. (2019). Human resource development (HRD) practices and banking industry effectiveness. European Journal of Training and Development, 43(3/4), 250-271. 10.1108/ejtd-07-2018-0068

Qiu, S., Alizadeh, A., Dooley, L. M., \& Zhang, R. (2019). The effects of authentic leadership on trust in leaders, organizational citizenship behavior, and service quality in the Chinese hospitality industry. Journal of Hospitality and Tourism Management, 40, 77-87. 10.1016/j.jhtm.2019.06.004

Robbins, S. P., \& Judge, T. A. (2017). Organizational Behavior (17 ed.). Pearson Education Limited.

Tsai, C.-W. (2015). Leadership style and employee's job satisfaction in international tourist hotels. Advances in Culture, Tourism, and Hospitality Research, 2, 293-332. 10.1108/13660750610665008

Uhl-Bien, M., Schermerhorn Jr, J. R., \& Osborn, R. N. (2016). Organizational Behavior (13 ed.). John Wiley \& Sons, Inc. 